\title{
Natural Gas or Algal Reef: Survey-Based Valuations of Pro-Gas and Pro-Reef Groups Specifically for Policy Advising
}

\author{
Yun-Ju Chen, Sheng Ming Hsu, Shu-Yi Liao, Tsung-Chi Chen and Wei-Chun Tseng * \\ Department of Applied Economics, National Chung Hsing University, 145 Xingda Rd., South Dist., \\ Taichung City 402, Taiwan; yjc2010@nchu.edu.tw (Y.-J.C.); donnyhsu1978@gmail.com (S.M.H.); \\ sliao@nchu.edu.tw (S.-Y.L.); d103034003@mail.nchu.edu.tw (T.-C.C.) \\ * Correspondence: tweichun@nchu.edu.tw
}

Received: 25 October 2019; Accepted: 5 December 2019; Published: 9 December 2019

\begin{abstract}
Much energy-related construction causes environmental concern. Sometimes the environmental issue is so huge that it is difficult to make a policy decision even with the assistance of traditional valuation techniques. The third natural gas receiving station at Datan, Taiwan, is one example of this. The construction would be beneficial to energy security, economic development, and particulate matter (PM) 2.5 reduction. However, it would destroy a precious algal reef, which is a habitat for endangered species, biodiversity, and a unique ecological system. Thus, we used willingness-to-pay to show the strength of both pro-energy and pro-ecology opinions specifically to help with decision-making. First, respondents were asked to choose between the gas station and the reef. Then they were asked about their willingness to pay for that choice. We then estimated parametric/nonparametric models-traditional probit, structured probit, and Turnbull-to obtain reliable estimates. We found that the per-person value for pro-gas-station respondents was higher than that for pro-reef respondents, while the percentage of pro-reef respondents was higher than the percentage of pro-gas-station respondents. These results together form a clear policy implication for this case.
\end{abstract}

Keywords: natural gas; contingent valuation method; algal reef; probit; structured probit; endangered species; energy and ecology

\section{Introduction}

Many energy-related facilities cause environmental concerns [1]. Some energy-related events have the same impact on everyone. For example, the famous Exxon Valdez oil spill had a negative ecological impact on all citizens. Furthermore, many energy-related facilities are highly controversial, making it difficult for governments to make decisions. The third natural gas receiving station at Datan, located in Taoyuan County in Taiwan, is one example. It is an important energy facility that has a high positive value, but because it would destroy a precious algal reef [2], it also has a high negative value. There are major benefits associated with the construction of the third natural gas receiving station, including energy security, economic development, and particulate matter (e.g., PM 2.5) reduction. However, the algal reef in the Datan area is valuable and has abounding biodiversity and endangered species that need to be preserved.

There are two liquefied natural gas (LNG) fueling stations available in Taiwan. For comparison, as of 2019, approximately 75 LNG fueling stations were available in the United States [3]. Taiwan is trying to build its third LNG station. The proposal was initiated from the previous government's plan for prudent nuclear reduction, and the current government's goal of a non-nuclear-powered homeland is at stake. In August 2017, the single-day reserved capacity rate of power generation in Taiwan 
dropped to only $1.72 \%$. If the third natural gas receiving station cannot supply gas as scheduled in 2022 , the reserved capacity will decrease by $2.6 \%$ in that year, failing to reach a power supply stability target of $10 \%$.

Contingent valuation is a survey-based technique that has been used for the valuation of environmental issues. While these environmental or ecological resources do give people utility, certain aspects do not have a market price, as they are not directly sold. Usually, the survey asks how much money the interviewee would be willing to pay to maintain the existence of an environmental feature, such as the algal reef in the third natural gas receiving station project. However, it is a case where the environmental issue is so huge that it is difficult to make a decision even with the assistance of traditional contingent valuation techniques, because the algal reef in Taoyuan County, including the Datan area, is the largest such ecosystem in Taiwan. It is 7500 years old [4] and abundant in biological diversity. There are several species in the area that are endangered, such as Chai-Shan multihole coral [2], which is one of Taiwan's 52 endangered animal species and is, therefore, very valuable. In addition, there are several endemic species of reef-building creatures, and there is also a new species of octopus waiting to be named. Furthermore, the endangered Taiwan white dolphin, whose population is considered to be around 60, has been observed in the Datan region.

The Taoyuan algal reef performs similar ecosystem functions to a coral reef. However, algal reefs are mainly found below $10 \mathrm{~m}$ in temperate waters [5] and rarely in subtropical and tropical oceans. The algal reef ecosystem in this subtropical area of northwest Taiwan is unique [6] and, thus, a natural heritage of humankind. The rapid decline of coral reefs is being reported worldwide, with different effects across regions. There are similar threats to algal reefs [2]. This particular reef's one-of-a-kind endemic species population, topography, and ecosystem exists nowhere else in the world. In March 2019, the Datan algal reef was declared the first ecological Hope Spot in East Asia by the conservation group Mission Blue.

Liao et al. [6] specifically developed a parametric method that estimates the willingness to pay (WTP) of people who support and oppose an energy policy; it is useful in this circumstance. Inspired by Liao et al. [6], we used both parametric and nonparametric models for the two groups to provide more reliable results in the current research. Hsu et al. estimated the value of the Taoyuan algal reef with a moderate sample size [7]. However, from 2014 to 2019, there were many changes in Taiwan. First, the algal reef was listed as the first marine Hope Spot. Second, it was frequently reported on by the media from 2014 to 2019 and became a focal point of energy, environment, economics, and politics in Taiwan. Third, energy queries in the referendum in 2018 also increased citizens' awareness of the third gas station and its potential damage to the algal reef at Datan (Figure 1). Finally, people's preferences may also have changed in those years; thus, a new investigation may be needed.

Social acceptance is crucial to assist the government and others in power in making better energy-related policy decisions [3,8,9]. It is evident that the opinions of both the pro-algal-reef group and the pro-gas group regarding the third gas station at Datan are strong, and the strength of their values is high. However, the exact magnitude of strength has not been quantified and understood. Thus, research directly focusing on this issue and with a larger sample size is needed.

Therefore, this study used willingness-to-pay to show the strength of opinions to help with decision-making. First, the respondents were asked to select between the construction of the third natural gas receiving station project (Group I) or the preservation of the algal reef (Group II). Then, we estimated several parametric and nonparametric models for model specification tests. The structured probit is new in contingent valuation, to the best of our knowledge. It is consistent with the single-bounded probit model but allows a structural break. The structural break makes the model more flexible than the traditional binary probit model. 


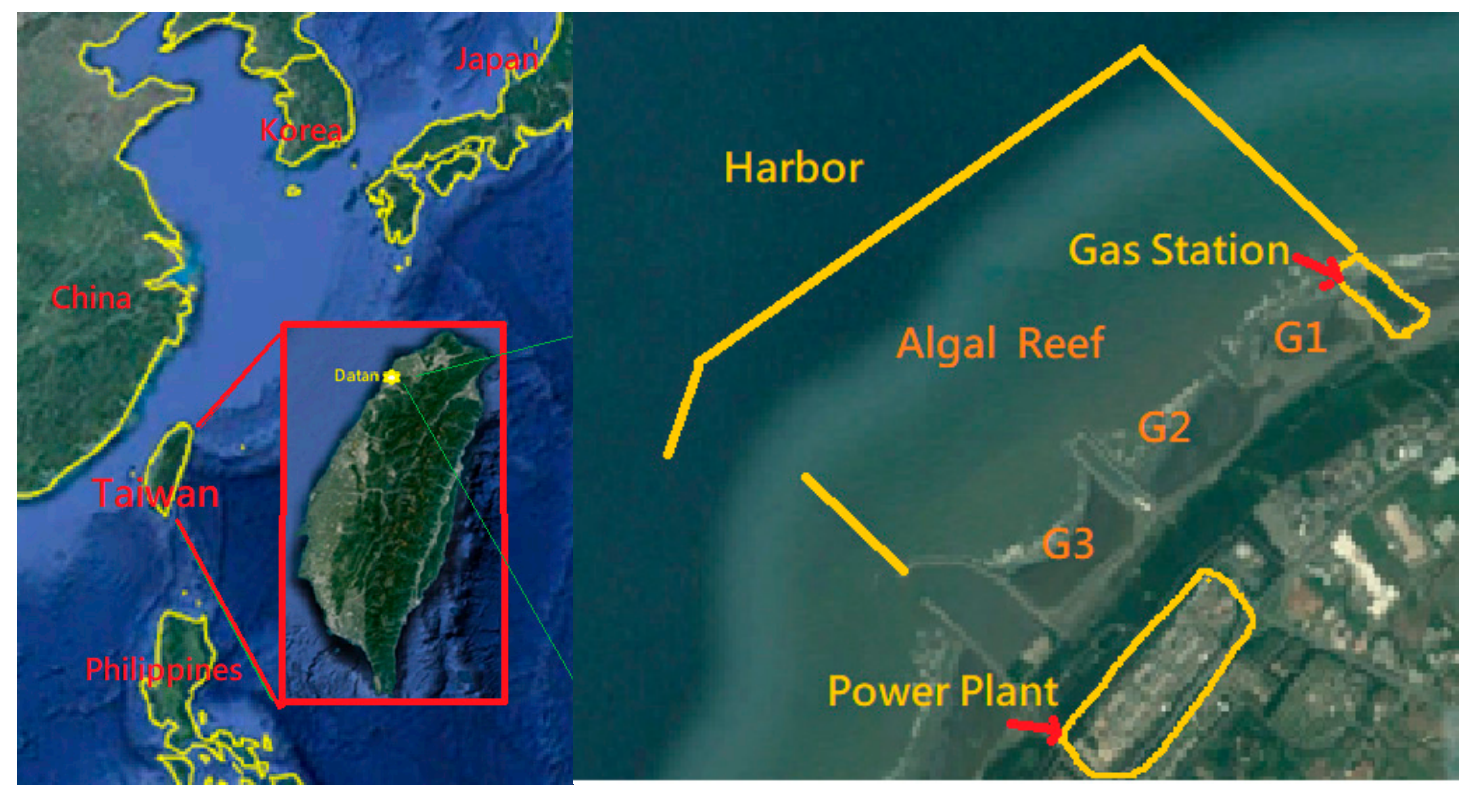

Figure 1. The locations of the Third Gas Station and Algal Reefs (G1, G2, G3). (The figure is based on Google Earth 2019 Terra Metrics and Maxar Technologies.).

\section{Literature Review}

Valuation studies using the contingent valuation method (CVM) and choice experiments related to energy issues are abundant [9]. These studies cover a wide range of topics, such as renewable energy [10-12], nuclear [3,9,13], coal [14,15], and other subjects, such as the carbon issue [16] and energy structures [17-19]. There are also studies related to other aspects of natural gas, such as the shortage risks [20]. However, value studies related to natural gas, although important, are relatively uncommon.

Several value studies are directly related to natural gas. First, household natural gas security was studied by Damigos et al. and by Kim et al. [11,21]. Damigos et al. used 793 observations by telephone survey to estimate Greek households' willingness to pay (WTP) for securing natural gas generating electricity [21]. The Kaplan-Meier product limit nonparametric estimator and parametric estimator (Tobit, interval data, least squared) were used. They found that the household WTP was between $6.3 €$ and $26.6 €$ per year. Kim et al. used the choice experiment method to estimate the value of improving household natural gas supply reliability in South Korea [11]. More than $80 \%$ of households in South Korea use natural gas; thus, this is an interesting issue. They found that households were willing to pay a $0.10 \%, 2.94 \%, 5.16 \%$, and $1.94 \%$ increase in their residential natural gas bill for shorter supply interruptions, avoidance of winter interruptions, prevention of interruptions during off-daytime rather than daytime hours, and prevention of interruptions during weekdays rather than weekends, respectively.

Jang et al. used a one-and-one-half-bound dichotomous choice model combined with a spike model to find that the average WTP for an increase in the Korean LNG storage rate from $11 \%$ to $20 \%$ was USD8.68 [22]. Moreira and Caetano used the CVM to estimate the WTP for marine-use LNG in contrast to less environmentally friendly traditional fuels [23]. They found that the WTP value was about 6.6-7.2€ per person. The health, climate, and nonhealth benefits were 9.7 million $€$, 8 million $€$, and 1053 million $€$, respectively, and the social costs were 1053 million $€$. In addition, Kim et al. used the translog production function to find that the value of industrial natural gas (ING) was USD2.07 per $\mathrm{m}^{3}$, which was 3.61 times as much as the average price [24]. Though not directly estimating the WTP of natural gas, Woo et al. found that Korean households were willing to pay USD1.80 per month to replace nuclear power with renewables or LNG [19]. However, the willingness to pay for the construction of the third gas station and harbor in Taiwan has not been estimated before. 
In contrast, valuation related to marine environments (including beaches, coral reefs, seagrass meadows, mangroves, and coastal areas) accounts for a large percentage (about $18.4 \%$ ) of the ecosystem services research in the past 20 years [25]. Coral reefs provide recreational services (diving, fishing, snorkeling, viewing) [26] and other functions (fish and marine life habitats, ocean clearing, biodiversity, etc.) and are, thus, highly valuable. The valuation of coral reefs started in the late 1980s, and there are more than 100 studies [27].

Coral reef valuation can be based on an ecosystem viewpoint. De Groot et al. estimated the value of ecological systems, and coral reefs are among the major habitats in the ecological system [28]. Based on 94 studies, De Groot et al. (2012) found that coral reefs provided, on average, 352,249 international dollars (INTD) per ha. per year, with a standard deviation of 668,639 INTD per ha. per year. Meanwhile, Spalding et al. estimated the coral reef value for tourists based on the ecosystem and the global scale [29]. They found that the value was, on average, USD482,428 per square kilometer per year.

Coral reef valuation often uses one or both major nonmarket valuation techniques; the travel cost method [30-32] and the contingent valuation method [30,32-34].

Coral reef valuation can also use meta-analysis [26,35]. Brander et al. used meta-analysis and the benefit transfer technique to estimate the recreational value of coral reefs [27]. They found that the global average was USD184 per person per visit. Using 85 observations from 27 studies with the contingent valuation method (CVM) or the travel cost method (TCM), Londoño and Johnston, taking account of heterogeneity in culture, currency, habits, and reef status, improved the coral reef meta-regression model [35].

There are many valuation studies regarding coral reefs, but besides the current research, there is only one other study, by Hsu et al. (2014), about algal reef value. In addition, there are several studies valuing the coral reefs in Taiwan. Tseng et al. estimated the overall impact of climate change on coral reefs for all of Taiwan [36]. Chen et al. studied the impact of oil spills on coral reefs in Kenting National Park [37]. Maynard et al. used a payment-card CVM and internet survey to estimate tourists' WTP for coral reef protection in Kenting National Park [27]. Lastly, Lee et al. [38] used a random parameter logit choice experiment (CE) method with an in-person survey to estimate the value of different types of visitors regarding the Kenting coral reef.

The contingent valuation method is designed to elicit preferences [39-44]. The merit of contingent valuation is that it can estimate values besides recreational usage. Thus, for our purpose, the CVM is most suitable. However, the energy-related algal reef protection issue in Taiwan is extremely controversial, and the government may not even know whether they should build the gas station or protect the algal reef. Thus, the traditional CVM is not sufficient to assist policy decisions in this case. The combined double-bounded model developed by Liao et al. [6], which combines the data from the two groups, provides a possible solution. Inspired by Liao et al. [6], the current research modified the traditional CVM to allow for the incorporation of survey results of both the pro-gas-station and pro-algal-reef groups. By doing so, the opinions of the public are more clearly demonstrated, and the value estimation is more useful.

\section{Methodology}

We estimated several parametric models for the purpose of covariate and model specification tests, and nonparametric models for estimating WTP to show the strength of each group (Figure 2). The parametric models included the traditional probit model and the structured probit for each group. The nonparametric model was the Turnbull model. The structured probit is new in contingent valuation and is an extension of the traditional probit. We introduce probit in Section 3.1 and structured probit in Section 3.2. We then explain the equation for the Turnbull WTP after the estimation. The double-bounded (DB) dichotomous choice framework has higher statistical efficiency than the single-bounded framework. However, we did not collect the response of the second bid; thus, it is not 
possible for us to estimate a DB model. Fortunately, a single-bounded framework has the merit of being incentive-compatible in the sense that true preference-telling is the best strategy for the respondent.

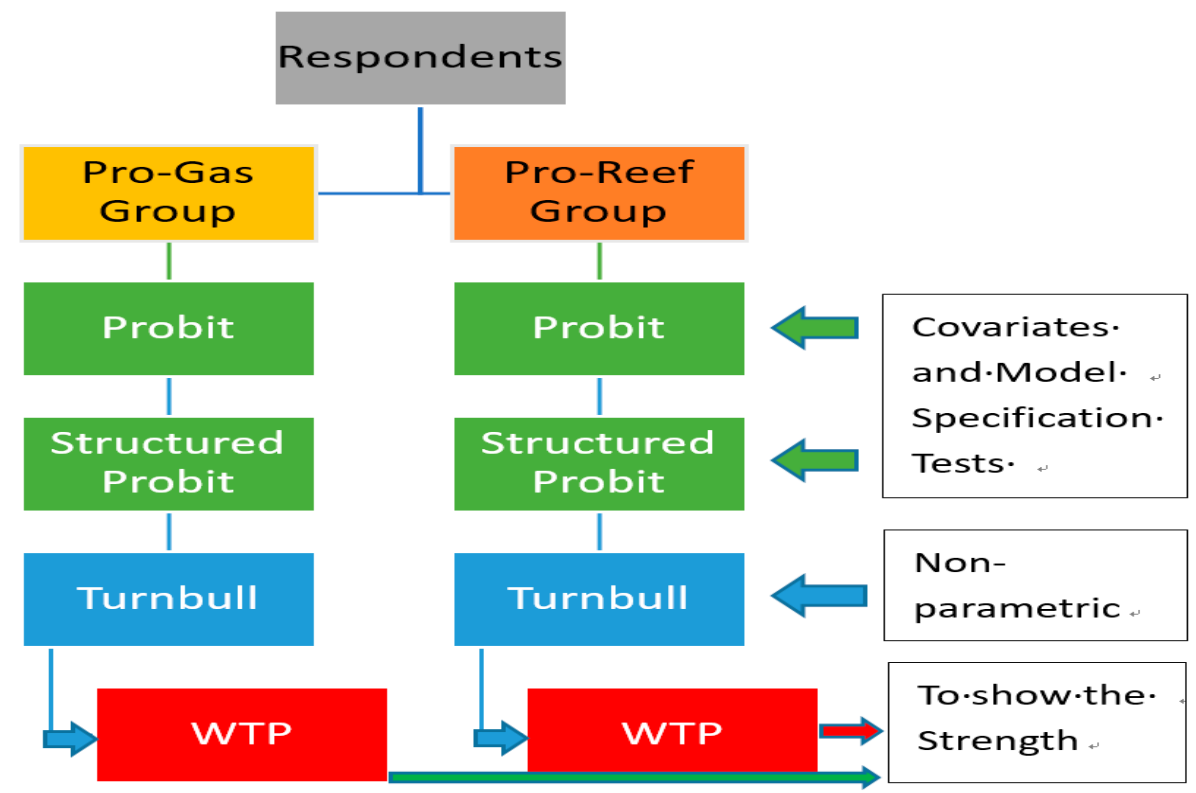

Figure 2. Case study map. WTP, willingness to pay.

\subsection{Traditional Probit}

There are two frameworks for the probit model: the indirect utility difference by Hanemann [45], and expenditure difference beginning with Hanemann [45] and Cameron and James [46]. We closely followed the latter, organized by Haab and McConnell [41]. Furthermore, we assumed it was consistent with linear WTP, and we assumed that the marginal utility of the offered price variable was the same as that of income; thus, income was canceled.

Hanemann [45] constructed the basic dichotomous model based on the random utility theory developed by McFadden. The indirect utility for interviewee $\mathrm{j}$ can be defined as

$$
U_{i j}=U_{i}\left(y_{j}, \quad W_{j}, \varepsilon_{i j}\right)
$$

where $i=1$ is the final state when the $C V$ project is implemented, and $i=0$ is the status quo; $y_{j}$ is interviewee $j$ 's income; $W_{j}$ is a vector of the interviewee's characteristics and other attributes; and $\varepsilon_{i j}$ represents stochastic parts of the utility function known to the interviewee but not observable by the researcher [41].

Assuming that the marginal utility of income does not vary in both statuses, one can derive the utility difference as follows:

$$
V_{1 j}-V_{0 j}=\alpha W_{j}-\beta t_{j}
$$

where $V$ is the deterministic part of the utility, $\alpha$ is a vector of coefficients, $\beta$ is a specific coefficient (which is the marginal utility of the income), and $t_{j}$ is the offered price. With the deterministic part of the preference specified, one can derive the probability of an interviewee saying yes to a WTP question as follows:

$$
\operatorname{Pr}(Y E S)=\operatorname{Pr}\left(\alpha W_{j}-\beta t_{j}+\varepsilon_{j}\right) .
$$

The probability of an interviewee saying no to the question will be $1-\operatorname{Pr}(Y E S)$. The WTP with a linear utility function can be defined as

$$
\alpha_{1} W_{j}+\beta\left(y_{j}-W T P_{j}\right)+\varepsilon_{1 j}=\alpha_{0} W_{j}+\beta\left(y_{j}\right)+\varepsilon_{0 j} .
$$


Alternatively, based on the expenditure difference framework, the WTP is the amount of income that makes the interviewee indifferent between the status quo and the final state:

$$
v_{1}\left(y_{j,}-W T P\left(y_{j}, W_{j}, \varepsilon_{j}\right), W_{j}\right)+\varepsilon_{1 j}=v_{0}\left(y_{j}, W_{j}\right)+\varepsilon_{0 j} .
$$

Assuming that willingness to pay $W T P_{j}$ is linear in attributes with an additive stochastic preference term of the interviewee, $j(j=1, \ldots, n)$ :

$$
W T P_{j}=W_{j}^{\prime} \gamma+\eta_{j}
$$

where $\gamma$ is a vector of the coefficients, and $\eta_{j}$ is the error term following a normal distribution $\mathrm{N}\left(0, \sigma^{2}\right)$. Finally, the problem can be converted to a traditional probit model by dividing $\sigma$ :

$$
\operatorname{Pr}\left(\left(W_{j}^{\prime} \gamma-t_{j}\right)>\eta_{j}\right)=\operatorname{Pr}\left(\left(W_{j}^{\prime} \gamma-t_{j}\right) / \sigma>\theta_{j}\right) .
$$

Then, one can construct the likelihood function and use commercial software, such as SAS or EViews, to estimate the coefficients, recover the preference, and calculate the WTP.

\subsection{Structured Probit}

The structured probit model [47] is a CVM model with a structure break. Borjas and Sueyoshi [48] used group-specific exogenous vectors and a two-stage estimator in their structured probit model. The structured probit model is new in contingent valuation, to the best of our knowledge. We use maximum likelihood to estimate coefficients directly. To merge the structural probit into the CV framework, we assume that it has a linear functional form, the general form of $W T P_{j}$ of the interviewee, $\mathrm{j}(\mathrm{j}=1, \ldots, \mathrm{n})$ :

$$
W T P_{j}=X_{B j}^{\prime} \theta_{1}+X_{A j}^{\prime} \theta_{2}+\eta_{j}
$$

where $X_{B j}^{\prime}$ is a vector of the exogenous variables before the break (in a continuous break variable case) or of the exogenous variables associated with subgroup $B$ (in a discrete break variable case, such as in [48]). Similarly, $X_{A j}^{\prime}$ is a vector of the exogenous variables after the break (in a continuous break variable case) or of the exogenous variables associated with subgroup A (in a discrete break variable case). $\theta_{1}$ is a vector of the coefficients before the break (or associated with group $B$ ) and $\theta_{2}$ is a vector of the coefficients after the break (or associated with group A). Assume the coefficient associated with the offered price is the same before and after the break (or for both groups in the discrete case). Further, assume the coefficient associated with the offered price is the same. Since $\eta_{j}$ follows a normal distribution $\mathrm{N}\left(0, \sigma^{2}\right)$, the problem can be converted to a structured probit model in contingent valuation by dividing $\sigma$ :

$$
\operatorname{Pr}\left(\left(X_{B j}^{\prime} \theta_{1}+X_{A j}^{\prime} \theta_{2}^{\prime}-t_{j}\right)>\eta_{j}\right)=\operatorname{Pr}\left(\left(X_{B j}^{\prime} \theta_{1}+X_{A j}^{\prime} \theta_{2_{j}^{\prime}}-t_{j}\right) / \sigma>\theta_{j}\right) .
$$

One can construct the log-likelihood function to estimate the coefficients, recover the preference, and calculate the WTP, similar to the steps after Equation (7). Since, in the extreme case, $\theta_{1}$ can be identical to $\theta_{2}$, it degenerates into the traditional probit model. Thus, the probit model with a structure break is a generalization of the traditional probit model. One can estimate and find a breaking point along a continuous exogenous variable. In our application, we used a discrete exogenous variable, gender, as the structure break. Thus, it was like using a vector of dummy variables for all exogenous variables in the estimation. We used GAUSS software to write the routines and maximum likelihood estimation (MLE) to estimate the coefficients.

\subsection{Survey and Statistical Data}

Following Haab and McConnell's suggestion, a better survey has at least two stages [41]. Thus, we tested several versions of the pre-survey questionnaires for fluency and whether they would 
be easily understood by the respondents. The questionnaire followed the National Oceanic and Atmospheric Administration (NOAA) guidelines [49,50]. The in-person survey mode was chosen, as suggested by Arrow et al. [49]. The respondents were reminded that they had a limited income and that there were many important ways to spend it. They were also reminded that there were many other important energy and ecological issues in Taiwan. All these steps were designed to reduce embedding effects and obtain reliable answers.

There were 6 parts in the survey questionnaire: (1) methods to generate electricity, (2) the third gas station and industrial harbor, (3) the algal reef ecology, (4) preference regarding the gas station or the algal reef, (5) the WTP main question, and (6) demographic data. We provided the information while collecting the respondents' attitudes and preferences. The respondents were asked to select between the construction of the third natural gas receiving station project (Group I) and the preservation of the algal reef (Group II). Then each respondent was asked separately about the WTP for her/his choice.

The official pre-survey had an open-ended format and was conducted face-to-face by a professional survey company from 12 to 14 March 2019 to obtain the frequencies of willingness to pay for both groups (Table 1). Then, we followed Alberini in choosing 4 offered prices for each group [51]. These offered prices were used in the closed-ended, dichotomous formal survey, and thus, there were 4 categories of questionnaires, according to the offered prices.

The offered prices were as follows: 500 and 200 New Taiwan Dollars(NTD) for Group I and Group II, respectively, in category A; 1000 NTD for Groups I and II in category B; 1500 and 1600 NTD for Group I and Group II, respectively, in category C; and 3000 NTD for Groups I and II in category D. Meanwhile, each respondent randomly answered one of the 4 questionnaires in the formal survey; the numbers of questionnaires for categories A, B, C, and D were 268, 267, 267, and 266, respectively.

The formal survey was conducted face-to-face, as suggested by the NOAA guidelines, from 13 to 29 April 2019 by the same survey company. Systematic random sampling was employed, based on the city and regional statistical report of the government. The entire country was divided into north, central, south, and east, and in each area city, zone, county, and township were the smallest sampling units. Finally, 30 cities, zones, counties, and townships were drawn, and the number of respondents in each unit was proportional to the census data. Two small island counties (Kin-men and Pen-Hu) were excluded due to time and budget constraints. The effective sample size was 1068, and under the 95\% statistical confidence level, the sampling error was $3 \%$.

Table 1. Willingness to pay (WTP) values in the official pre-survey.

\begin{tabular}{ccc}
\hline Group I Prefer Gas Station & Group II Prefer Algal Reef \\
\hline WTP & Frequency & Frequency \\
\hline 100 & 3 & 2 \\
200 & 1 & 2 \\
300 & 1 & - \\
500 & 5 & 1 \\
600 & 1 & - \\
800 & - & 1 \\
1000 & 11 & 4 \\
1200 & 1 & 1 \\
1500 & 2 & - \\
1600 & - & 1 \\
1800 & - & 1 \\
2000 & 3 & 1 \\
2400 & 1 & 1 \\
3000 & 5 & 3 \\
4000 & 1 & - \\
5000 & - & 1 \\
6000 & 1 & - \\
10,000 & 2 & - \\
12,000 & - & 1 \\
Total & 38 & 20 \\
\hline
\end{tabular}

Notes: All amounts are in new Taiwan dollars (NTD). 
We made the information balanced and precise. For example, we asked:

Do you know that the size of the land development area of the third natural gas receiving station has been revised to 23 hectares (about as large as 15 baseball fields) and is located in the existing building area? The construction area of the offshore industrial port is also about as large as 15 baseball fields. Finally, the size of the underwater dredging area is about 60 baseball fields. All these constructions will cause damage to the ecology of the algae reef. (1) Yes, I know; (2) No, I do not know.

Each interviewer wore ID and took the questionnaire and gifts to the sampled places to conduct the interviews. Visual conditions can affect the WTP in coral studies [32,52-54]. Thus, as suggested by the NOAA guidelines to provide clear color photos, we provided photos of the algal reef and a photo showing an area out of electricity to remind the respondents of the importance of the gas station to ensure better provision of electricity (Figure 3) [46,49].

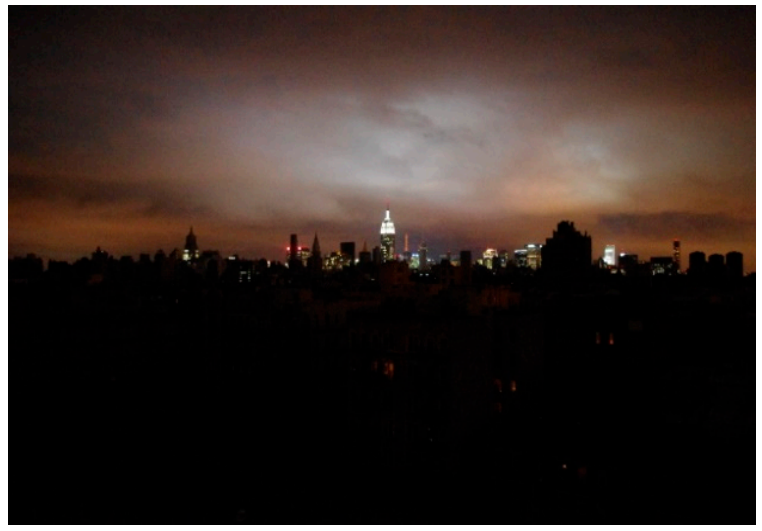

(a)

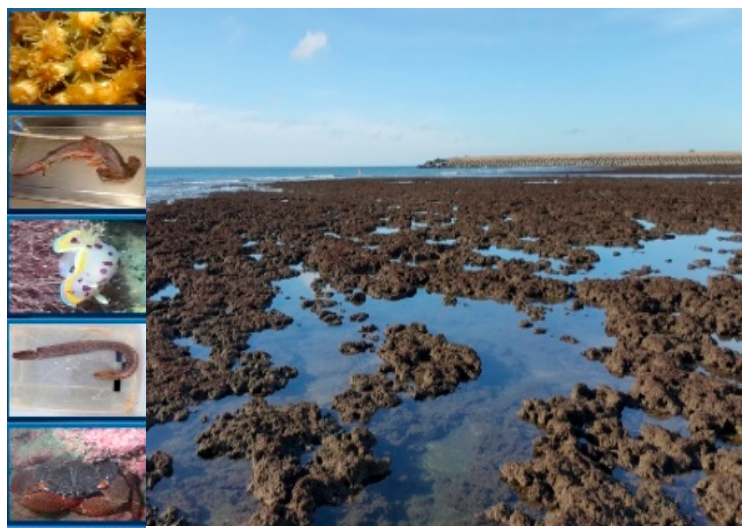

(b)

Figure 3. (a) An area out of electricity in summer 2017; (b) algal reef; endangered species, such as Taiwan white dolphin, Sphyrna lewini shark, Polycanthus chaishanensis, Phymatolithon sp, and Mesophyllum $s p$, and a new species of octopus waiting to be named, have been found there.

First, the respondent chose between options $\mathrm{G}$ and $\mathrm{R}$ (Table 2), where option $\mathrm{G}$ is the gas station construction (with certain damage to the algal reef), and option $R$ is no construction (thus, the algal reef is relatively well protected). Then, the respondent answered the closed-ended, willingness-to-pay question.

Suppose the respondent randomly faced the category D questionnaire. She/he first had to choose between options G and R (Table 2). The respondent was classified as Group I if she/he chose option G, and was classified as Group II if she/he chose option R.

Table 2. Options for pro-gas and pro-reef.

\begin{tabular}{|c|c|c|}
\hline \multirow{2}{*}{ Dimension } & Option G & Option R \\
\hline & $\begin{array}{l}\text { Build the Third Natural Gas Receiving } \\
\text { Station and the Industrial Harbor }\end{array}$ & Protect the Algal Reef \\
\hline Electricity & Backup electricity capability increases $2.6 \%$ & Backup electricity does not increase \\
\hline Ecology & $\begin{array}{l}\text { Algal reefs on land or in the sea will be } \\
\text { damaged to a certain extent }\end{array}$ & Algal reef is preserved \\
\hline
\end{tabular}

Participants who were classified into Group I were then told that option $\mathrm{G}$ was now associated with a payment (Table 3). If the respondent chose option $\mathrm{G}$ again, then she/he was considered as saying yes to the offered price of 3000 NTD. If the respondent chose option R in this round, then she/he was considered as saying no to the offered price. 
Similarly, those in Group II were told that option R was now associated with a payment. The respondent then chose between options $G$ and $R$ in a table similar to Table 2, but with a positive payment associated with option $\mathrm{R}$ and zero payment associated with option $\mathrm{G}$. Table 4 summarizes the frequencies and percentages of the answers.

Table 3. Dichotomous choice question for electing WTP.

\begin{tabular}{|c|c|c|}
\hline \multirow[b]{2}{*}{ Dimension } & Option G & Option R \\
\hline & $\begin{array}{l}\text { Build the Third Natural Gas Receiving } \\
\text { Station and the Industrial Harbor }\end{array}$ & Protect Algal Reefs \\
\hline Electricity & Backup electricity capability increases $2.6 \%$ & Backup electricity does not increase \\
\hline Ecology & $\begin{array}{l}\text { Algal reef on land or in the sea will be } \\
\text { damaged to a certain extent }\end{array}$ & Algal reef is preserved \\
\hline Pay & 3000 NTD per year & 0 NTD \\
\hline
\end{tabular}

Table 4. Frequencies and percentages of answers to bids for both groups.

\begin{tabular}{|c|c|c|c|c|c|c|c|}
\hline \multirow{2}{*}{$\begin{array}{c}\text { Offered } \\
\text { Price } \\
\text { (Bids) }\end{array}$} & \multicolumn{3}{|c|}{$\begin{array}{c}\text { Group I: Prefer Construction of } \\
\text { Natural Gas Station }\end{array}$} & \multirow{2}{*}{$\begin{array}{c}\begin{array}{c}\text { Offered } \\
\text { Price }\end{array} \\
\text { (Bids) }\end{array}$} & \multicolumn{3}{|c|}{$\begin{array}{c}\text { Group II: Prefer Protection of Algal } \\
\text { Reef }\end{array}$} \\
\hline & Frequency & $Y^{a}$ & $\mathbf{N}$ & & Frequency & $Y$ & $\mathbf{N}$ \\
\hline 500 & 70 & $\begin{array}{c}53 \\
\left(75.72^{b}\right)\end{array}$ & $\begin{array}{c}17 \\
(24.28)\end{array}$ & 200 & 198 & $\begin{array}{c}157 \\
(79.29)\end{array}$ & $\begin{array}{c}41 \\
(20.70)\end{array}$ \\
\hline 1000 & 67 & $\begin{array}{c}45 \\
(67.17) \\
\end{array}$ & $\begin{array}{c}22 \\
(32.83) \\
\end{array}$ & 1000 & 200 & $\begin{array}{c}142 \\
(71.00)\end{array}$ & $\begin{array}{c}58 \\
(29.00)\end{array}$ \\
\hline 1500 & 73 & $\begin{array}{c}37 \\
(50.69)\end{array}$ & $\begin{array}{c}36 \\
(49.31)\end{array}$ & 1600 & 194 & $\begin{array}{c}146 \\
(75.25)\end{array}$ & $\begin{array}{c}48 \\
(24.74)\end{array}$ \\
\hline 3000 & 69 & $\begin{array}{c}36 \\
(52.18)\end{array}$ & $\begin{array}{c}33 \\
(47.82)\end{array}$ & 3000 & 197 & $\begin{array}{c}126 \\
(63.95)\end{array}$ & $\begin{array}{c}71 \\
(36.04)\end{array}$ \\
\hline
\end{tabular}

${ }^{a}$ Y means the respondent accepted the bid, and $\mathrm{N}$ means the respondent rejected the bid. ${ }^{\mathrm{b}}$ Numbers in parentheses are percentages in relation to frequencies for respective rows.

The no rate increased as the bid price increased, with 2 exceptions, which was consistent with our expectations. Meanwhile, the no rate for preferring to protect the algal reef tended to be low. The reason is that in the formal survey questionnaire, the harbor (and its damage to the algal reef) was included as part of the gas station construction because we found out that the sole purpose of the new harbor will be to service the gas station (while the harbor was not in the official pre-survey questionnaire). The demographic aspects of the survey were similar to those of the Census Bureau records, except that the education level was higher.

\section{Results and Discussion}

The descriptive statistics of the formal survey are presented in Table 5. Since many estimations are separately presented for each group, Table 5 shows the descriptive statistics for Groups I and II.

We estimated several parametric models and a nonparametric model as the model specification tests to obtain reliable estimates. These were the traditional and structured probit models for each group separately and the Turnbull nonparametric model.

First, we estimated the probit for Groups I and II separately (Table 6). The offered prices were negative and significant, as expected. For Group I, the WTP measured how strongly respondents preferred construction of the natural gas station. Those whose knowledge came from the Taiwan Power Company had a lower WTP. Those whose knowledge came from the environmental group had a higher WTP. In addition, those who understood that sand moved by construction in the sea would be the cause of damage to the algal reef had a higher WTP. 
For Group II, the WTP measured how strongly respondents preferred protection of the algal reef. Men had a higher WTP, elders had a lower WTP, and those with no strong preference regarding political party had a higher WTP. Finally, respondents from larger families had a lower WTP. The likelihood tests for each estimation passed the significance level at $99 \%$, indicating that the estimations were reliable.

We then estimated the structured probit for Group I (those who preferred construction of the natural gas station) and Group II (those who preferred protection of the algal reef). The structured probit we employed is consistent with the single-bounded probit model (as in Haab and McConnell) [39] but allows a structure break. The structure break makes the model more flexible than the traditional binary probit model. A typical structure break is based on a continuous variable; here, we based this on a discrete variable (gender); thus, the effect is like using a dummy variable on all coefficients. Furthermore, it was consistent with linear WTP, and we assumed that the marginal utility of the offered price variable was the same as that of income; thus, income was canceled. We tried family or age as the threshold coefficient, and while there was no qualitative difference, gender had the best overall performance econometrically.

Table 5. Definitions and descriptive statistics of variables.

\begin{tabular}{|c|c|c|c|c|c|}
\hline \multirow{2}{*}{ Name } & \multirow{2}{*}{ Definition } & \multicolumn{2}{|c|}{ Group I } & \multicolumn{2}{|c|}{ Group II } \\
\hline & & Mean & Std. Dev. & Mean & Std. Dev. \\
\hline YN_GS & Yes/no for Group I & 0.612 & 0.487 & - & - \\
\hline YN_Reef & Yes/no for Group II & - & - & 0.723 & 0.447 \\
\hline priceGS & Offered price for Group I & 1.500 & 0.933 & - & - \\
\hline pricReef & Offered price for Group II & - & - & 1.446 & 1.024 \\
\hline Gender & $\begin{array}{l}\text { Dummy variable: } 1 \text { for male, } \\
0 \text { for female }\end{array}$ & 0.584 & 0.493 & 0.512 & 0.500 \\
\hline Age & $\begin{array}{l}\text { Age of respondent } \\
\text { (divided by 100) }\end{array}$ & 0.418 & 0.143 & 0.374 & 0.133 \\
\hline Similar & $\begin{array}{l}\text { No strong preference regarding } \\
\text { political party }\end{array}$ & 0.387 & 0.487 & 0.378 & 0.485 \\
\hline Family & Number of people in family & 4.157 & 1.837 & 4.070 & 1.762 \\
\hline KTP & $\begin{array}{l}\text { Knowledge came from Taiwan } \\
\text { Power Company }\end{array}$ & 0.193 & 0.395 & 0.178 & 0.383 \\
\hline KEG & $\begin{array}{l}\text { Knowledge came from } \\
\text { environmental group }\end{array}$ & 0.053 & 0.225 & 0.226 & 0.334 \\
\hline GRO & $\begin{array}{l}\text { Understand that the groin effect is } \\
\text { a main cause of algal reef damage }\end{array}$ & 0.322 & 0.468 & 0.190 & 0.392 \\
\hline Respondents & Number of respondents & \multicolumn{2}{|c|}{279} & \multicolumn{2}{|c|}{789} \\
\hline
\end{tabular}

Notes: While YN_GS is a dependent variable for Group I and YN_Reef is a dependent variable for Group II in many estimations, other variables are exogenous variables in the estimations.

Table 6. Estimation of coefficients of the probit model for each group.

\begin{tabular}{|c|c|c|c|c|}
\hline \multirow{2}{*}{ Items } & \multicolumn{2}{|c|}{ Group I: Prefer Construction of Natural Gas Station } & \multicolumn{2}{|c|}{ Group II: Prefer Protection of Algal Reef } \\
\hline & Coeff. & $p$-Value & Coeff. & $p$-Value \\
\hline Price & $-0.2400^{* * *}$ & 0.0045 & $-0.1535^{* * *}$ & 0.0011 \\
\hline Constant & 0.4690 & 0.1914 & $1.2979 * * *$ & 0.0000 \\
\hline Gender & -0.0047 & 0.9770 & $0.1883 *$ & 0.0548 \\
\hline Age & 0.4454 & 0.4307 & $-1.1449^{* * *}$ & 0.0016 \\
\hline Similar & -0.1076 & 0.5159 & $0.2375^{* *}$ & 0.0212 \\
\hline Family & -0.0249 & 0.5596 & $-0.0568^{* *}$ & 0.0366 \\
\hline KTP & $-0.3950 *$ & 0.0562 & -0.1561 & 0.2108 \\
\hline KEG & $0.6430 *$ & 0.0964 & 0.0605 & 0.6837 \\
\hline GRO & $0.6647^{* * *}$ & 0.0004 & 0.2131 & 0.1033 \\
\hline Log-likelihood & \multicolumn{2}{|c|}{-172.958} & \multicolumn{2}{|c|}{-445.332} \\
\hline
\end{tabular}


The offered price was negative and significant, as expected in the structured probit for Group I (Table 7). The WTP measured how strongly the respondent preferred construction of the natural gas station. Men in Group I, whose knowledge came from the electric company, had a lower WTP, and older women had a higher WTP. In addition, both genders had a higher WTP as long as they understood that sand moved by construction in the sea would be the cause of damage to the algal reef. The likelihood test passed the significance level at $99 \%$, indicating that the estimations were reliable. These results are similar to those in Table 6; thus, justifying our model specifications.

Table 7. Estimation of coefficients of structured probit model for Group I (those who preferred construction of natural gas station).

\begin{tabular}{ccccc}
\hline \multirow{2}{*}{ Item } & \multicolumn{2}{c}{ Male } & \multicolumn{2}{c}{ Female } \\
\cline { 2 - 5 } & Coeff. & $p$-Value & Coeff. & $p$-Value \\
\hline Price & $-0.2616^{* * *}$ & 0.0027 & $\mathrm{a}$ & $\mathrm{b}$ \\
\hline Constant & 0.4963 & 0.1535 & $\mathrm{a}$ & $\mathrm{b}$ \\
\hline Age & -0.7644 & 0.2957 & $1.2847^{*}$ & 0.0690 \\
\hline Similar & 0.1995 & 0.4228 & -0.3592 & 0.1169 \\
\hline Family & 0.0789 & 0.2152 & -0.0771 & 0.1567 \\
\hline KTP & $-0.6007^{*}$ & 0.0514 & -0.2319 & 0.4287 \\
\hline KEG & 0.5333 & 0.4214 & 0.7192 & 0.1460 \\
\hline GRO & $0.7840^{* * *}$ & 0.0051 & $0.5953^{* *}$ & 0.0238 \\
\hline
\end{tabular}

Log-likelihood

$-168.125$

Notes: ${ }^{*}, * *$, and ${ }^{* * *}$ denote significance at the $10 \%, 5 \%$, and $1 \%$ level, respectively. a,b: Due to the model framework, there was only one offered price coefficient and one constant. The structured probit was based on gender. There were 134 women and 145 men in Group I.

The offered price was negative and significant, as expected in the structured probit for Group II (Table 8). Please note that the WTP measured how strongly the respondent preferred protection of the algal reef. Elders had a lower WTP, despite gender. Men in Group II whose knowledge came from the electric company had a lower WTP. In addition, both genders had a higher WTP as long as they understood that sand moved by construction in the sea would be the cause of damage to the algal reef. The likelihood test also passed the significance level at $99 \%$, indicating that the estimations were reliable.

Table 8. Estimation of coefficients of structured probit model for Group II (those who preferred protection of algal reef).

\begin{tabular}{ccccc}
\hline \multirow{2}{*}{ Items } & \multicolumn{2}{c}{ Male } & \multicolumn{2}{c}{ Female } \\
\cline { 2 - 5 } & Coeff. & $p$-Value & Coeff. & $p$-Value \\
\hline Price & $-0.1518^{* * *}$ & 0.0013 & $\mathrm{a}$ & $\mathrm{a}$ \\
\hline Constant & $1.4031^{* * *}$ & 0.0000 & $\mathrm{~b}$ & 0.0209 \\
\hline Age & $-1.3786^{* * *}$ & 0.0023 & $-1.0157^{* *}$ & 0.3147 \\
\hline Similar & $0.3346^{* *}$ & 0.0192 & 0.1495 & 0.1778 \\
\hline Family & $-0.0619^{*}$ & 0.0635 & -0.0503 & 0.6064 \\
\hline KTP & $-0.3886^{* *}$ & 0.0241 & 0.0946 & 0.9960 \\
\hline KEG & 0.1266 & 0.5671 & 0.0010 & 0.2803 \\
\hline GRO & $0.2341^{*}$ & 0.2116 & 0.1986 &
\end{tabular}

Notes: ${ }^{*}, * *$, and ${ }^{* * *}$ denote significance at the $10 \%, 5 \%$, and $1 \%$ levels, respectively. a,b: Due to the model framework, there was only one offered price coefficient and one constant. Structured probit was based on gender. There were 385 women and 404 men in Group II. 
We asked those who were willing to pay about their preferred mode of payment (Table 9). Most people preferred an increased electricity bill, followed by tax. We used these modes, as suggested by the literature, as exogenous variables and the results are robust.

Table 9. Mode of payment.

\begin{tabular}{ccccc}
\hline \multirow{2}{*}{$\begin{array}{c}\text { Payment } \\
\text { Mode }\end{array}$} & \multicolumn{2}{c}{$\begin{array}{c}\text { Group I: Prefer Construction of the } \\
\text { Natural Gas Station }\end{array}$} & \multicolumn{2}{c}{$\begin{array}{c}\text { Group II: Prefer Protection of } \\
\text { Algal Reef }\end{array}$} \\
\cline { 2 - 5 } & Frequency & Percentage & Frequency & Percentage \\
\hline Tax & 28 & 2.6 & 87 & 8.1 \\
\hline Voluntary & 7 & 0.7 & 69 & 6.5 \\
\hline $\begin{array}{c}\text { Increased } \\
\text { electricity bill }\end{array}$ & 136 & 12.7 & 409 & 38.3 \\
\hline Other modes & - & - & 6 & 0.6 \\
\hline Total & 171 & 16.0 & 571 & 53.5 \\
\hline
\end{tabular}

To be more confident in the results, we also estimated a nonparametric Turnbull model [41]. There are five merits to this method: (1) the restriction is minimized when calculating the WTP, (2) it does not require any assumptions of the distribution of the WTP, (3) the transparency of the process makes it a credible valuation method, (4) the WTP obtained is free from the impact of outliers, and (5) the sign of the WTP estimated using the Turnbull model is always as expected [41].

The percentage of respondents who are unwilling to pay may not monotonously increase when the offered price increases if the sample size is not large enough, there are too many offered prices, or the difference between the offered prices is small. Turnbull (1976) resolved this issue by pooling back categories to ensure monotonicity.

Equations (10) and (11) are Turnbull's nonparametric lower bound mean and lower bound variance of WTP, respectively. One can use the mean and the variance to calculate the $95 \%$ confidence interval (C.I.):

$$
\begin{gathered}
E_{L B}(W T P)=\sum_{j=0}^{M^{*}} t_{j} F_{j+1}^{*}-F_{j^{\prime}}^{*} \\
\mathrm{~V}\left(E_{L B}(W T P)\right)=\sum_{j=1}^{M^{*}} \frac{F_{j}^{*}\left(1-F_{j}^{*}\right)}{T_{j}^{*}}\left(t_{j}-t_{j-1}\right)^{2} .
\end{gathered}
$$

In Equations (10) and (11), $E_{L B}(W T P)$ is Turnbull's nonparametric lower bound mean WTP, $M^{*}$ is the total number of categories after pooling back, $\mathrm{V}\left(E_{L B}(W T P)\right)$ is Turnbull's nonparametric lower bound variance of WTP, $t_{j}$ is the offered price in each category (four categories for each group in this study), $T_{j}^{*}$ is the number of observations in each category after pooling back, $F_{j}$ is the no rate, and $F_{j}^{*}$ is the no rate after pooling back. Following Haab and McConnell [41], we conducted the nonparametric Turnbull estimation for those who preferred construction of the natural gas station (Table 10) and those who preferred protection of the algal reef (Table 11).

With the numbers in Tables 10 and 11, we used Equations (10) and (11) to calculate Turnbull's nonparametric lower bound mean WTP and the variance of WTP. Then, using the mean and variance, we calculated the 95\% C.I. as usual (Table 12). The mean WTP for Group I, who preferred construction of the natural gas station, was USD55.905 per person per year. The 95\% C.I. was between USD53.150 and 58.659. Furthermore, the mean WTP for Group II, who preferred protection of the algal reef, was USD36.160 per person per year, with the 95\% C.I. between USD31.699 and 40.621. However, only 279 respondents supported the gas receiving station, outnumbered by 789 respondents who supported preservation of the algal reef. Please note that a total of $30.52 \%$ of respondents were unwilling to pay. Indeed, this is a high percentage that cannot go unnoticed if the objective is to extrapolate measures of 
payment to the entire Taiwanese population. The magnitudes and even signs of WTP obtained by parametric models are often not plausible [41]. The nonparametric Turnbull model always produced WTP values with signs as expected; thus, we provide the nonparametric WTP results.

Table 10. Turnbull estimates with pooling for those preferring construction of the natural gas station.

\begin{tabular}{|c|c|c|c|c|c|c|}
\hline \multirow{3}{*}{$\begin{array}{c}\begin{array}{c}\text { Offered } \\
\text { Price }\end{array} \\
\mathbf{t j}\end{array}$} & \multirow{3}{*}{$\begin{array}{c}\begin{array}{c}\text { Number of } \\
\text { Nos }\end{array} \\
\mathbf{N j}\end{array}$} & \multicolumn{2}{|c|}{ Nobs } & \multicolumn{3}{|c|}{ No Rate } \\
\hline & & \multirow{2}{*}{$\mathbf{T} \mathbf{j}$} & \multirow{2}{*}{$\mathbf{T} \mathbf{j} *$} & \multirow{2}{*}{$\begin{array}{c}\text { Unrestricted } \\
\mathrm{Fj}\end{array}$} & \multicolumn{2}{|c|}{ Turnbull } \\
\hline & & & & & $\mathbf{F j}$ * & $\mathrm{Fj}^{*}$ \\
\hline 500 & 17 & 70 & 70 & 0.2428 & 0.2428 & 0.2428 \\
\hline 1000 & 22 & 67 & 67 & 0.3283 & 0.3283 & 0.0855 \\
\hline 1500 & 36 & 73 & 142 & 0.4931 & 0.4859 & 0.1575 \\
\hline 3000 & 33 & 69 & Pooled back & 0.4782 & Pooled back & Pooled back \\
\hline $3000+$ & - & - & - & - & 1 & 0.5140 \\
\hline
\end{tabular}

Notes: When the offered price increased from 1500 to 3000 NTD, the no rate (number of those saying no to the offered price divided by Nobs) did not monotonically increase (column 5); thus, the fourth row was pooled back. Tj is the number of observations in each category, $\mathrm{T} j$ is the number of observations in each category, $\mathrm{T}^{*}$ is the number of observations after pooling back, $\mathrm{Nj}$ is the number of nos, $\mathrm{Fj}^{*}$ is the no rate after pooling back, and $\mathrm{fj}^{*}$ is the change of the no rate after pooling back.

Table 11. Turnbull estimates with pooling for those preferring protection of algal reef.

\begin{tabular}{ccccccc}
\hline $\begin{array}{c}\text { Offered } \\
\text { Price }\end{array}$ & $\begin{array}{c}\text { Number of } \\
\text { Nos }\end{array}$ & \multicolumn{2}{c}{ Nobs } & \multicolumn{3}{c}{ No Rate } \\
\hline $\mathbf{t j}$ & $\mathbf{N j}$ & $\mathbf{T j}$ & $\mathbf{T j}{ }^{*}$ & Unrestricted & $\mathbf{F j}^{*}$ & $\mathbf{F j}^{*}$ \\
\hline 200 & 41 & 198 & 198 & 0.2070 & 0.2070 & 0.2070 \\
\hline 1000 & 58 & 200 & 394 & 0.2900 & 0.2690 & 0.0619 \\
\hline 1600 & 48 & 194 & Pooled back & 0.2474 & Pooled back & Pooled back \\
\hline 3000 & 71 & 197 & 197 & 0.3604 & 0.3604 & 0.0913 \\
\hline $3000+$ & - & - & - & - & 1 & 0.6395 \\
\hline
\end{tabular}

Notes: When the offered price increased from 1000 to 1600 NTD, the no rate did not monotonically increase (column 5); thus, the third row was pooled back. $\mathrm{T} j$ is the number of observations in each category, $\mathrm{Tj}$ is the number of observations in each category, $\mathrm{Tj}^{*}$ is the number of observations after pooling back, $\mathrm{Nj}$ is the number of nos, $\mathrm{Fj}^{*}$ is the no rate after pooling back, and $\mathrm{fj}^{*}$ is the change of the no rate after pooling back.

The CPC company plans to invest USD20 billion (i.e., 20 thousand million) in this project. The planned quantity of LNG to be transported through tank ships will be three million tons per year beginning in 2025. The user price of natural gas is around USD0.33 to 0.39 per cubic meter, depending on the user (private electric company, household, public unit, etc.) and the season (summer, winter). Thus, the natural gas transported by the third natural gas station will be about USD1306-1544 million per year. Carbon dioxide $\left(\mathrm{CO}_{2}\right)$ efficiency is 1.753 tons $\mathrm{CO}_{2} /$ ton $\mathrm{LNG}$ vs. 2.535 tons $\mathrm{CO}_{2} /$ ton of coal. Thus, transporting LNG through this station rather than using coal would reduce $\mathrm{CO}_{2}$ emissions by 2.346 million tons. Multiplied by the European Union market price of USD21.8-22.2 per ton, the environmental benefit from reducing $\mathrm{CO}_{2}$ emissions would be about USD 51.18-52.25 million per year. In addition, the electricity produced by LNG transported through this project would be about half that of a nuclear power plant. Thus, both the benefits and costs are significant. 
Table 12. Willingness to pay (WTP) values for each group.

\begin{tabular}{cccccc}
\hline \multicolumn{2}{c}{ Group I: Prefer } & \multicolumn{2}{c}{ Construction of Natural Gas Station } & \multicolumn{3}{c}{ Group II: Prefer Protection of Algal Reef } \\
\hline Mean & Std. & $\mathbf{9 5 \%}$ C.I. & Mean & Std. & 95\% C.I. \\
\hline 55.905 & 1.405 & $(53.150,58.659)$ & 36.160 & 2.276 & $(31.699,40.621)$ \\
\hline
\end{tabular}

Notes: Figures are in USD. On 9 September 2019, USD 1= 30.84 NTD buying and 31.51 NTD selling by the Taiwan Bank. The average was USD1 $=31.17$ NTD.

The WTP values obtained in this research make sense and are justified by both domestic and international comparisons among similar studies. While it is not easy to compare our research to that of Kim et al. [24], both our research and theirs found that the natural-gas-related value is high. In addition, our natural-gas-related value estimates are somewhat higher than those of Damigos et al., Jang et al., Moreira and Caetano, and Kim et al. [11,21-23]. This could be due to the fact that the goods evaluated (LNG station and harbor vs. natural gas (NG) storage proportion, marine-use LNG, or residential-use LNG), methods (dichotomous CVM vs. choice experiment, Tobit, and the ordinary least squared regression), years, and countries in the studies were different.

Algal reefs are rarer than coral reefs. Only one study has estimated the value of algal reefs [7]. Hsu et al. used the probit and logit models to estimate the value of the Taoyuan algal reef ecosystem and found that willingness to pay was valued at USD14.11 and USD15.08, respectively [6]. Compared to previous Taiwanese studies, the current research obtained higher values for preservation of the algal reef than Hsu et al. [7]. A possible reason is that in March 2019, the Taoyuan algal reef was listed as the first marine Hope Spot in East Asia by the international conservation organization Mission Blue. Additionally, the reef has been reported on frequently by the media since 2014 and has become a focal point of energy, environment, economics, and politics in Taiwan. Media reports can affect people's viewpoints. Furthermore, the energy quarries in the referendum in 2018 also increased citizens' awareness of the algal reef at Datan. In addition, the current research estimated the values of both the pro-algal-reef and pro-gas groups, while Hsu et al. only estimated the value of protecting the reef. Thus, the current research has a larger scope. Furthermore, the sample size of the current research was larger than that in Hsu et al. [7].

Several research studies have investigated the value of coral reefs in Taiwan, varying in terms of location, scenario (climate change, oil spread, etc.), and method. Tseng et al. estimated the potential damage to coral reefs in Taiwan caused by climate change [36]. They found the average annual personal willingness to pay to be valued at around USD35.75. Chen et al. estimated the economic loss due to an oil spill in Kenting National Park in Taiwan [37] and found an average WTP value of USD44.66 per person per year. Maynard et al. estimated the value of coral ecosystems in Kenting National Park and found the average value to be USD80.16 per person per year [27]. Finally, Lee et al. found that the average value of integrated management for the ecosystem, including a $25 \%$ increase in coral coverage was about USD6.02 per trip [38].

There are more than 100 estimates of coral reefs in other countries. Though they are not directly comparable based on algal reef vs. coral reef, different methods, different units, etc., we tried to compare the results of selected studies. For example, Brander et al. used meta-analysis based on many other studies and found that the worldwide average value of coral reef recreation was USD184 per person per visit [26]. Recently, Robles-Zavala and Reynoso [52] determined the recreational value of coral reefs for domestic and international tourists at the three major tourist spots in the Mexican Pacific. Using the dichotomous choice contingent valuation method, they found willingness to pay to be valued at USD5.79 for conservation activities.

We reviewed several selected CVM studies that estimated coral reef-related values. For example, Park et al. found snorkeling visits to the Florida Keys were valued at USD43.7 per person per day [30]. Bhat found that the Florida Keys reef-related value was USD134.0-196.7 per person per day [31]. Mathieu et al. found the value of marine parks in the Seychelles to be USD13.1 per person per day [33]. Anderson found the recreational cost of coral bleaching of international tourists to be valued 
at USD49.7-117.4 per person per day [32]. Finally, Asafu-Adjaye and Tapsuwan found the value of scuba diving in Mu Ko Similan Marine National Park, Thailand, to be USD24.8-62.6 per person per day [34].

The WTP in the current research is higher than that of Hsu et al. [7] and Lee et al. [38] and comparable to Tseng et al., while it is lower than that of Chen et al. and Maynard et al. [27,36,37]. Compared to coral reef values in other countries, our findings are higher than those of Mathieu et al. [31] and Robles-Zavala and Reynoso [51], comparable to those of Park et al., and lower than those of Bhat, Anderson, and Brander et al. [26,30-32]. Despite the fact that there may be bias caused by relatively high education levels in our sample, the value estimates of the current research appear to be bounded by similar studies both domestically and internationally. Therefore, the values obtained by the current research are justified.

\section{Conclusions}

In Taiwan, as in many other countries, opinions regarding energy-related facilities are diverse. This implies that when estimating social acceptance, different methods are needed. Therefore, we estimated willingness to pay to show the strength of both the group in favor of the gas receiving station and the group in favor of preservation of the algal reef to help with decision-making. Parametric models, including the traditional probit and structured probit for each group, were used for efficiency. We also estimated a nonparametric model to obtain reliable willingness to pay values.

We found that the value for each group of Taiwanese people was high. The mean WTP for those who preferred construction of the natural gas station and the harbor was USD55.905 per person per year, while the mean WTP for those who preferred protection of the algal reef was USD36.160 per person per year. However, the percentage of pro-reef respondents was higher than the percentage of pro-gas-station respondents. Therefore, the overall strength for the algal reef was about 1.83 times more than for the gas receiving station. The policy implication of our finding is that the third natural gas station should be reconsidered, and it might be necessary to find other energy projects or energy-saving measures. These results can be a reference for the Taiwanese government to make an informed decision.

This research fills a gap in the studies evaluating the environmental impact of natural gas construction and adds to the limited algal reef valuation literature. Many positive and negative externalities have been considered. Compared to a very expensive political referendum that can be adopted in an election, this paper provides low-cost approaches, and countries may use it to help formulate their energy/ecology policy to overcome demanding decision challenges in complex real-world phenomena.

Author Contributions: Conceptualization, Y.-J.C.; investigation, S.-Y.L.; supervision, W.-C.T.; validation, T.-C.C.; writing—original draft, S.M.H.; writing—review and editing, S.M.H.

Funding: The authors acknowledge that this research was sponsored by the Ministry of Science and Technology, Taiwan (grant number MOST 107-2410-H-005-003-SSS). The work was also partially funded by the Academia Sinica, Taiwan.

Acknowledgments: The authors would like to thank the editor and two anonymous reviewers for their constructive comments. The authors would like to thank the Biodiversity Research Center of the Academia Sinica, the Datan Algae Reef Action Alliance and Chongcheng Pan, the Central News Agency, CPC Corporation in Taiwan, the Industrial Development Bureau of the Ministry of Economic Affairs in Taiwan, the Taiwan Environmental Protection Administration, and the Google company for providing the photos and information used for this study. However, any errors are the sole responsibility of the authors.

Conflicts of Interest: The authors declare no conflicts of interest.

\section{References}

1. Cook, D.; Davíðsdóttir, B.; Kristófersson, D.M. Energy projects in Iceland-Advancing the case for the use of economic valuation techniques to evaluate environmental impacts. Energy Policy 2016, 94, $104-113$. [CrossRef] 
2. Liou, C.-Y.; Yang, S.-Y.; Chen, C.A. Unprecedented calcareous algal reefs in northern Taiwan merit high conservation priority. Coral Reefs 2017, 36, 1253. [CrossRef]

3. Alternative Fuels Data Center. Available online: https://afdc.energy.gov/fuels/natural_gas_stations.html (accessed on 5 October 2019).

4. Dai, C.F.; Wang, S.W.; Chang, J.S.; Jeng, A.I. Handbook for Ecological Tours of Guanyin Algae Reef; CPC Corporation: Taichung City, Taiwan, 2009.

5. Gibson, R.; Atkinson, R.; Gordon, J. Mediterranean coralligenous assemblages: A synthesis of present knowledge. Oceanogr. Mar. Biol. Annu. Rev. 2006, 44, 123-195.

6. Liao, S.-Y.; Tseng, W.-C.; Chen, C.C. Eliciting Public Preference for Nuclear Energy against the Backdrop of Global Warming. Energy Policy 2010, 38, 7054-7069. [CrossRef]

7. Hsu, S.H.; Tseng, W.C.; Chen, C.C. Assessment of the economic value of the Taoyuan Algal Reef ecosystem. Taiwan Agric. Econ. Rev. 2014, 20, 1-31. (In Chinese)

8. Jun, E.; Kim, W.J.; Jeong, Y.H.; Chang, S.H. Measuring the social value of nuclear energy using contingent valuation methodology. Energy Policy 2010, 38, 1470-1476. [CrossRef]

9. Huh, S.-Y.; Woo, J.; Lee, C.-Y. What Do Potential Residents Really Want When Hosting a Nuclear Power Plant? An Empirical Study of Economic Incentives in South Korea. Energies 2019, 12, 1199. [CrossRef]

10. Stigka, E.K.; Paravantis, J.A.; Mihalakakou, G.K. Social acceptance of renewable energy sources: A review of contingent valuation applications. Renew. Sustain. Energy Rev. 2014, 32, 100-106. [CrossRef]

11. Kim, H.-J.; Kim, S.-M.; Yoo, S.-H. Economic Value of Improving Natural Gas Supply Reliability for Residential Consumers in South Korea. Sustainability 2019, 11, 515. [CrossRef]

12. Kowalska-Pyzalska, A. Do Consumers Want to Pay for Green Electricity? A Case Study from Poland. Sustainability 2019, 11, 1310. [CrossRef]

13. Carlson, D.E.; Ripberger, J.T.; Jenkins-Smith, H.C.; Silva, C.L.; Gupta, K.; Berrens, R.P.; Jones, B.A. Contingent valuation and the policymaking process: An application to used nuclear fuel in the United States. J. Benefit-Cost Anal. 2016, 7, 459-487. [CrossRef]

14. Lee, H.-C.; Lee, E.-B.; Alleman, D. Schedule Modeling to Estimate Typical Construction Durations and Areas of Risk for 1000 MW Ultra-Critical Coal-Fired Power Plants. Energies 2018, 11, 2850. [CrossRef]

15. Lin, B.; Jia, Z. Economic, energy and environmental impact of coal-to-electricity policy in China: A dynamic recursive CGE study. Sci. Total Environ. 2020,698, 134241. [CrossRef] [PubMed]

16. Lee, S.-Y.; Lee, I.-B.; Han, J. Design under uncertainty of carbon capture, utilization and storage infrastructure considering profit, environmental impact, and risk preference. Appl. Energy 2019, 238, 34-44. [CrossRef]

17. Aravena, C.; Hutchinson, W.G.; Longo, A. Environmental pricing of externalities from different sources of electricity generation in Chile. Energy Econ. 2012, 34, 1214-1225. [CrossRef]

18. Strazzera, E.; Mura, M.; Statzu, V. Powering the change: A Contingent Valuation study on the determinants of demand for green vs. brown energy. J. Environ. Econ. Policy 2012, 1, 146-173. [CrossRef]

19. Woo, J.; Lim, S.; Lee, Y.-G.; Huh, S.-Y. Financial feasibility and social acceptance for reducing nuclear power plants: A contingent valuation study. Sustainability 2018, 10, 3833. [CrossRef]

20. Tchórzewska-Cieślak, B.; Pietrucha-Urbanik, K. Approaches to Methods of Risk Analysis and Assessment Regarding the Gas Supply to a City. Energies 2018, 11, 3304. [CrossRef]

21. Damigos, D.; Tourkolias, C.; Diakoulaki, D. Households' willingness to pay for safeguarding security of natural gas supply in electricity generation. Energy Policy 2009, 37, 2008-2017. [CrossRef]

22. Jang, J.; Lee, J.; Yoo, S.-H. The public's willingness to pay for securing a reliable natural gas supply in Korea. Energy Policy 2014, 69, 3-13. [CrossRef]

23. Moreira, P.J.P.; Caetano, F.J. Liquefied Natural Gas as an alternative fuel: A regional-level social cost-benefit appraisal. East. Eur. Bus. Econ. J. 2017, 3, 122-161.

24. Kim, H.-J.; Han, S.-M.; Yoo, S.-H. Measuring the Economic Benefits of Industrial Natural Gas Use in South Korea. Sustainability 2018, 10, 2239. [CrossRef]

25. Costanza, R.; De Groot, R.; Braat, L.; Kubiszewski, I.; Fioramonti, L.; Sutton, P.; Farber, S.; Grasso, M. Twenty years of ecosystem services: How far have we come and how far do we still need to go? Ecosyst. Serv. 2017, 28, 1-16. [CrossRef]

26. Brander, L.M.; Van Beukering, P.; Cesar, H.S. The recreational value of coral reefs: A meta-analysis. Ecol. Econ. 2007, 63, 209-218. [CrossRef] 
27. Maynard, N.; Château, P.-A.; Ribas-Deulofeu, L.; Liou, J.-L. Using Internet Surveys to Estimate Visitors' Willingness to Pay for Coral Reef Conservation in the Kenting National Park, Taiwan. Water 2019, 11, 1411. [CrossRef]

28. De Groot, R.; Brander, L.; Van Der Ploeg, S.; Costanza, R.; Bernard, F.; Braat, L.; Christie, M.; Crossman, N.; Ghermandi, A.; Hein, L. Global estimates of the value of ecosystems and their services in monetary units. Ecosyst. Serv. 2012, 1, 50-61. [CrossRef]

29. Spalding, M.; Burke, L.; Wood, S.A.; Ashpole, J.; Hutchison, J.; Zu Ermgassen, P. Mapping the global value and distribution of coral reef tourism. Mar. Policy 2017, 82, 104-113. [CrossRef]

30. Park, T.; Bowker, J.M.; Leeworthy, V.R. Valuing snorkeling visits to the Florida Keys with stated and revealed preference models. J. Environ. Manag. 2002, 65, 301-312. [CrossRef]

31. Bhat, M.G. Application of non-market valuation to the Florida Keys marine reserve management. J. Environ. Manag. 2003, 67, 315-325. [CrossRef]

32. Andersson, J.E. The recreational cost of coral bleaching-A stated and revealed preference study of international tourists. Ecol. Econ. 2007, 62, 704-715. [CrossRef]

33. Mathieu, L.F.; Langford, I.H.; Kenyon, W. Valuing marine parks in a developing country: A case study of the Seychelles. Environ. Dev. Econ. 2003, 8, 373-390. [CrossRef]

34. Asafu-Adjaye, J.; Tapsuwan, S. A contingent valuation study of scuba diving benefits: Case study in Mu Ko Similan Marine National Park, Thailand. Tour. Manag. 2008, 29, 1122-1130. [CrossRef]

35. Londoño, L.M.; Johnston, R.J. Enhancing the reliability of benefit transfer over heterogeneous sites: A meta-analysis of international coral reef values. Ecol. Econ. 2012, 78, 80-89. [CrossRef]

36. Tseng, W.W.-C.; Hsu, S.-H.; Chen, C.-C. Estimating the willingness to pay to protect coral reefs from potential damage caused by climate change-The evidence from Taiwan. Mar. Pollut. Bull. 2015, 101, 556-565. [CrossRef] [PubMed]

37. Chen, C.-C.; Tew, K.S.; Ho, P.-H.; Ko, F.-C.; Hsieh, H.-Y.; Meng, P.-J. The impact of two oil spill events on the water quality along coastal area of Kenting National Park, southern Taiwan. Mar. Pollut. Bull. 2017, 124, 974-983. [CrossRef] [PubMed]

38. Lee, C.-H.; Chen, Y.-J.; Chen, C.-W. Assessment of the Economic Value of Ecological Conservation of the Kenting Coral Reef. Sustainability 2019, 11, 5869. [CrossRef]

39. Whitehead, J.C.; Blomquist, G.C.; Hoban, T.J.; Clifford, W.B. Assessing the validity and reliability of contingent values: A comparison of on-site users, off-site users, and non-users. J. Environ. Econ. Manag. 1995, 29, 238-251. [CrossRef]

40. Carson, R.T.; Hanemann, W.M.; Kopp, R.J.; Krosnick, J.A.; Mitchell, R.C.; Presser, S.; Ruud, P.A.; Smith, V.K.; Conaway, M.; Martin, K. Referendum design and contingent valuation: The NOAA panel's no-vote recommendation. Rev. Econ. Stat. 1998, 80, 335-338. [CrossRef]

41. Haab, T.C.; McConnell, K.E. Valuing Environmental and Natural Resources: The Econometrics of Non-Market Valuation; Edward Elgar Publishing: Bodmin, UK, 2002.

42. Liu, J.T.; Hammitt, J.K.; Wang, J.D.; Tsou, M.W. Valuation of the risk of SARS in Taiwan. Health Econ. 2005, 14, 83-91. [CrossRef]

43. Tseng, W.-C.; Chen, C.-C. Valuing the potential economic impact of climate change on the Taiwan trout. Ecol. Econ. 2008, 65, 282-291. [CrossRef]

44. Tseng, W.-C.; Chen, C.-C.; Chang, C.-C.; Chu, Y.-H. Estimating the economic impacts of climate change on infectious diseases: A case study on dengue fever in Taiwan. Clim. Chang. 2009, 92, 123-140. [CrossRef]

45. Hanemann, W.M. Welfare evaluations in contingent valuation experiments with discrete responses. Am. J. Agric. Econ. 1984, 66, 332-341. [CrossRef]

46. Cameron, T.A.; James, M.D. Efficient estimation methods for "closed-ended" contingent valuation surveys. Rev. Econ. Stat. 1987, 69, 269-276. [CrossRef]

47. Muthen, B. A Structural Probit Model with Latent Variables. J. Am. Stat. Assoc. 1979, 74, 807-811.

48. Borjas, G.J.; Sueyoshi, G.T. A Two-Stage Estimator for Probit Models with Structural Group Effects. J. Econom. 1994, 64, 165-182. [CrossRef]

49. Arrow, K.; Solow, R.; Portney, P.R.; Leamer, E.E.; Radner, R.; Schuman, H. Report of the NOAA panel on contingent valuation. Fed. Regist. 1993, 58, 4601-4614. 
50. Bateman, I.J.; Carson, R.T.; Day, B.; Hanemann, M.; Hanley, N.; Hett, T.; Jones-Lee, M.; Loomes, G.; Mourato, S.; Pearce, D.W. Economic Valuation with Stated Preference Techniques: A Manual; Edward Elgar Publishing: Cheltenham, UK, 2002.

51. Alberini, A. Efficiency vs bias of willingness-to-pay estimates: Bivariate and interval-data models. J. Environ. Econ. Manag. 1995, 29, 169-180. [CrossRef]

52. Robles-Zavala, E.; Reynoso, A.G.C. The recreational value of coral reefs in the Mexican Pacific. Ocean Coast. Manag. 2018, 157, 1-8. [CrossRef]

53. Farr, M.; Stoeckl, N.; Esparon, M.; Larson, S.; Jarvis, D. The importance of water clarity to Great Barrier Reef tourists and their willingness to pay to improve it. Tour. Econ. 2016, 22, 331-352. [CrossRef]

54. Grafeld, S.; Oleson, K.; Barnes, M.; Peng, M.; Chan, C.; Weijerman, M. Divers' willingness to pay for improved coral reef conditions in Guam: An untapped source of funding for management and conservation? Ecol. Econ. 2016, 128, 202-213. [CrossRef]

(C) 2019 by the authors. Licensee MDPI, Basel, Switzerland. This article is an open access article distributed under the terms and conditions of the Creative Commons Attribution (CC BY) license (http://creativecommons.org/licenses/by/4.0/). 